\title{
Featured Artist- Zhang Ping: Pioneering Ballroom Dance in China
}

\section{艺术家聚焦-张平 : 中国国际标准舞 ( 交谊舞 ) 先驱}

\author{
Tony Y Zhou ${ }^{1}$ LiQing Fan², XiaoYun Zheng ${ }^{3}$ \\ ${ }^{1}$ Inspirees Institute, China \\ ${ }^{2}$ Top China \\ ${ }^{3}$ Beijing Dance Academy, China
}

\begin{abstract}
Zhang Ping, born in 1956, is the leader of ballroom dance in China. Through written interview, this paper records professor Zhang Ping's contributions in the field of ballroom dance in recent years. As the founder of the ballroom dance subject of Beijing Dance Academy, how does professor Zhang Ping build up the subject step by step? And how to conduct cultural exchanges and docking work with western countries on the road of building Chinese ballroom dance? As a contemporary dancer and educator, professor Zhang Ping's views on ballroom dance? And how to view the Chinese and western art education and practice?
\end{abstract}

Key words: ballroom dance, International cultural exchanges and cooperation, Art education

\section{摘要}

张平，生于1956年，中国国际标准舞学科带头人。本文通过书面访谈的形式，记录了张 平教授近些年来在国际标准舞领域所做的贡献。身为北京舞蹈学院国际标准舞学科的创 建者，张平教授是如何一步一步将该学科建设起来 ? 又是如何在建设中国国标舞的道路 上，与西方国家进行文化交流与对接工作 ? 身为当代舞蹈家、教育家，张平教授对于国 际标准舞 (交谊舞) 的看法是怎样的 ? 又是如何看待中西方艺术教育与实践的问题的?

关键词 : 国际标准舞（交谊舞 ），国际文化交流与合作，艺术教育

Dr. Tony Zhou, the executive editor of CAET, interviewed Zhang Ping, for his pioneering work in China.

TZ: How do you look at the contribution of your work to the society? What is your own motivation to create new programs in the Beijing Dance Academy and bring dance and art out of the academy to the public?

ZP: The Social Music Dance Education Department started in the Beijing Dance Academy and began to recruit students in 1989, representing the formal establishment of dance. Within this framework, four sub-disciplines including international standard dance, musical, children's dance, and normal dance have been developed. Later, these 
sub-disciplines have grown into independent disciplines and became an important part of the department of the Beijing Dance Academy. They are the Ballroom Dance Department, Musical Drama Department, the School of Grade Examination, and the School of Education.

The motivation for the creation of social music dance education came from a conversation with President Lv Yisheng, a famous dancer, aesthetician, and former president of the Beijing Dance Academy. The conversation was about how a generation of college students can fill the gap of dance at the Beijing Dance Academy and align China's inverted dance pyramid. Chinese dance is compared to a pyramid emerging from the bottom and narrowing near the top, serving as a catalyst for mass dance to professional dance. Mass dance and social dance account for a small part of training, whereas professional dance and stage dance occupy the majority of the pyramid. President Lv Yisheng hopes that I can step forward and correct China's dance pyramid, so that social dance, mass dance, or the dance base of the people can become abundant and available to a broader audience. Objectively speaking, President Lv Yisheng is the designer of the dance pyramid, and I am his executive.

TZ:You were challenged by the colleagues in the West when you presented your work, which was associated with Confucian Institute. Can you please tell us more about it? How do you look at the cultural conflicts and how did you overcome the barrier and eventually establish the mutual dialogue with the West? What was/is your motivation in the international exchange/collaboration?

ZP: China is the most populous country in the world and has more than 3,000 years of culture. After decades of continuous development, China has made considerable progress in technology, architecture, and arts and has developed into one of the leading countries in the world. As a big country, China vacillates between its own hard power, through execution of military threats and economic inducements, and soft power, by persuading others to do what one wants. It is the polarity between coercion and persuasion, or between internal and external motivations, that pushes the barriers to reach a certain level to obtain cultural confidence. Cultural confidence may be found in dance art expression and serve as a catalyst to intercultural exchange.

Cultural diversity in an era when Chinese dance is going global may invite people from the Western culture to understand China more comprehensively. With the help of the Confucius Institute, a mature platform for cultural exchange, the establishment and operation of Confucius Institute for dance will play a special role in promoting Chinese dance to the world.

My experience in the process of promoting the Confucius Institute program is not the challenge from my Western colleagues, but the difference in ideas caused by the cultural difference between China and the West. In the cultural context of contemporary China, our standards for the beauty of dance and dancers are more inclined to the processed and beautified dance movements shown in the bodies of dancers with classical Chinese dance training. In contemporary Chinese culture, we generally consider the above criteria as the basis of a beautiful dance. In the process of communication, foreign counterparts, including university presidents and professors, tend to judge dance by its 
origin, local culture, traditional culture, style, and significance in cultivating the body. Of course, every culture in the world has its own sense of aesthetics. What I mean is that the aim is not to distinguish the advantages and disadvantages of different cultures, but to solve the problems caused by cultural differences in a diverse way when the two distinctive cultures of the East and the West collide and communicate with each other.

In my role at the Confucius Institute, I found that we have the same cognitive understanding of dance. The social function of dance is designed to educate the body and care for life. This is the consensus reached when the Confucius Institute was established, and it is also an important path for cultural exchanges between China and the West. There are cultural biases, which is an ongoing education for understanding each culture and art exchange. I decided to make corresponding adjustments according to Western habits, but I want to maintain Chinese dance culture too. These adjustments aim to eliminate the discomfort caused by cultural differences as much as possible when showing Chinese dance culture to foreign people, so that we can achieve a more fluid and efficient cultural dialogue.

Teaching the body to dance is a process, with the purpose of loving life, human beings, and nature. When it comes to my incentive for my pleasure in international exchange and cooperation, I hope Chinese and Western cultures can understand, respect, and interact with each other. In the context of the whole culture, we are closely related to each other and share similar views about the beauty in dance.

\section{TZ:Art has been affiliated with the ideology of the Communist Party in China. How do you look at this from an artist perspective?}

ZP: There is no denying that the influence of politics and ideology on art is a very common phenomenon all over the world. One example is the Hollywood film industry in the United States. From the written script to the final film production, Western ideological values are dominated by American individual heroism, unlike Eastern characteristics, which predominantly emphasize the collective group. As an artist, I personally believe that it is not advisable to artificially create opposition between culture and ideology. No matter what the ideology is, it should not excessively affect artistic creation. Of course, artistic creation can never be completely free from the restrictions of ideology. Although the art of our country has connection with ideology, it is beyond reproach.

China is a country with a long history and culture. The artistic creation with traditional culture as the theme and history is a very suitable choice for telling Chinese stories well. From a macro-perspective, only by maintaining the diversity of art and respecting the diversity under different cultures can the overall development of art be better promoted. The essence of art is to promote truth, goodness, and beauty of humanity.

\section{TZ:How has the art education and practice been transformed in the past 50 years in China in your eyes? How does China balance Western influence and its own tradition?}

ZP: Undoubtedly, after 50 years of development, China's art education has gradually formed its own system. People who practice art have made considerable progress on the basis of self-reliance and exploration of China's art tradition. In terms of art education, 
based on China's cultural and artistic traditions, we have formed a dance education system covering a diverse range in college education, middle, and primary schooling, and even preschool areas. This system includes quality education, professional education, and higher education. With regard to art practice, there is an increase in creative expression of traditional art culture and art creation within the last 50 years, after the Cultural Revolution.

In the process of China's art development, we have absorbed foreign factors, from mainly Western culture, and integrated them into our cultural arts training. On the basis of maintaining the distinction of Chinese art and culture, it has formed a contemporary Chinese culture that is in line with the aesthetic characteristics of today.

TZ:Why do you think ballroom dancing is so popular in China? Do you see it as filling a role in well-being (social, emotional, spiritual, or health) or is it something entirely different?

ZP: The popularity of ballroom dancing in China first reflects the broad inclusiveness of Chinese culture. After we accepted the foreign dance form of ballroom dance, we introduced it into the professional scene, providing excellent professional dancers with a channel to communicate with their foreign counterparts. Meanwhile, we popularized this kind of dance widely, thus gaining acceptance among ordinary family. Together with other dance forms such as Chinese folk dance, ballroom dance has promoted people's physical and mental health. Objectively speaking, China's reform and opening up helped ballroom dance survive and develop in China. The "academic" dance education system accelerates the growth of China's talent in ballroom dancing. The linkage of sports, entertainment, and artistic creation reflected in ballroom dancing with Chinese characteristics is also a big contribution to the world dance field.

\section{About the Author}

Tony Y Zhou, PhD, CMA, is the founder and executive editor of CAET journal, also the co-founder of Inspirees Institute in China.

LiQing Fan is an editor from Top China.

XiaoYun Zheng is a post graduate in the study of Ballroom dancing from Beijing Dance Academy, and the translator for this interview article

\section{About the Artist}

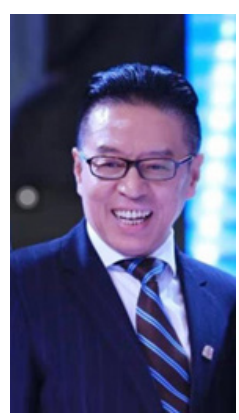

Zhang Ping is a professor and postgraduate mentor of Beijing Dance Academy. Former vice President of art committee and deputy director of education committee of China International Federation of Ballroom dance; Former presidium, executive director of Beijing Dancers Association and director of the working committee of Chinese ballroom dance; Senior examiner for international judges and senior adviser to the arts committee of the World Dance Council; National Cultural Trade Academic Research platform experts; Deputy chairman of the dance art committee of the Chinese Culture Promotion 
Association; Deputy chairman and secretary general of the community dance working committee of the Chinese Culture Promotion Association; Chairman of musical theatre committee and chief expert of committee of Chinese Culture Promotion Association. 